\title{
The Correlation of philosophy, Science, Religion, Education, Language, And Geography
}

\author{
${ }^{1 s t}$ Mustolikh \\ Universitas Muhammadiyah \\ Purwokerto \\ Indonesia \\ mustolikh@ump.ac.id
}

\author{
${ }^{2 n d}$ Sofyan Sauri \\ Indonesia University of Education \\ Indonesia \\ sofyansauri@upi.edu
}

\author{
${ }^{3 r d}$ Ahmad Syamsu Rizal \\ Indonesia University of Education \\ Indonesia \\ rizal@upi.edu
}

Abstract-- This study aimed to describe the correlation of (1) philosophy, science, and religion; (2)philosophy and education; (3) philosophy and language; adn (4) philosophy, geography, and religion.

This study used biblioghraphymethod, which aimed to collect the data of documents. This was a descriptive study which aimed to comprehensively describe about something (object, indication, or a certain group). Content analysisandinterpretation were applied as the methods of data analysis. Furthermore, hermeneutic circle and the combination between inductive and deductive methods were implemented to draw the conclusion.

Based on the problems examined by researchers, it could be concluded that: (1) philosophy, science, and religion correlated one another in answering the problems and in finding and discovering the truth; (2) the correlation between philosophy and education was connected to the logical

\section{INTRODUCTION}

Human as khalifatullah fil ardh, is blessed with the highest level of intelligence and knowledge. That was stated QS. Al 'Alaq [096]: 5. When human knows where he is from, how the process of creating human is, who he is, what he is created for, then he has philosophized at that time. Philosophy also produces metaphysical thing such as God philosophize. One of the perspectives of God philosophies is the perspective of hujjatulIslam al-Ghazali inTahafutul Falasifah (The Philosophers' Mistake). This condition creates the paradigm of most people about contradictory correlation between philosophy, science, and religion.

To solve the problems as mentioned above, this study aimed to describe the correlation of (1) philosophy, science, and religion; (2)philosophy problems (formal logics built by coherence principle) and dialectic problems that were based on the principles of contradictory acceptance and allowance; (3) philosophy provided the basis of language education process including the course, goals, and process bahasa tidak terlepas dari jasajasa filsafat yang memberikan dasarberpijak dari segala; and (4) the correlation of philosophy, geography, and religion contextually nurture the character of environmental care. Indonesian people must have the character of environmental care, thus they are able to do the responsibility as khalifatullah fil ardh.

Key words: philosophy, science, religion, education, language, and geography.

and education; (3) philosophy and language; and(4) philosophy, geography, and religion.

\section{METHODS}

This study was conducted through descriptive biblioghraphy method by describing an object, indications, or a certain group comprehensively. The method of data analysis used content analysis andinterpretation. Moreover, hermeneutic circle and the combination of inductive and deductive method were implemented in drawing the conclusions.

\section{RESULTS AND DISCUSSION}

\section{A. The correlation of Philosophy, Science, and Religion.}

According to Suseno (1995, p.20), philosophy is a critical science. In other words, 
philosophy can be defined as an interpretation or evaluation on an important or meaningful thingof life. Furthermore, Poedjawijatna (1980, p. 10) states that philosophy could be mentioned as a science that finds the deepest causes of everything based on the thoughts. He then categorizesphilosophy as a science, thus philosophy must be scientific; demanding the truth, having method, having system, and general prevailing.

Gazalba (1992, p.7) mentions that philosophy is the results of radical, systematic, and universal thinking. Here, radical means that the examined problems, the proposed questions, and the given answers have the quality of penetrating from the roots and finding the clarity and authenticity. Thus philosophy can be defined as reflective and critical thinking. Yet, Randall and Buchler quoted bySadulloh (2007, hlm.17) have critics on the statement above as: (1) the statement do not show the difference between philosophical thinking and the function of culture and history, (2) scientists reflectively and critically think that science and philosophy are different, and (3) the experts of law and economy as well as housewives sometime reflectively and critically think though they are not philosophers or scientists.

In Islamic perspective, the word shoposis equivalent to himah,then philosophy can be defined as hikmah love or loving himah (Bakar, 1997 , p. 102). Therefore, philosophy is a comprehensive or universal science that describes about anything exists and forms of something presents (Mulkan, 1993, p. 25). The present here means something having essences including God as God having essence of wajib al-wujud in Islamic perception. In addition, philosophy can be categorized as a science because both philosophy and science use thought.

The word science or ilmu is from Arabic 'alima-ya 'limu- 'ilman/ilmun, which means knowledge. Science is derived from Latin scio, cire, which means knowledge (Gazalba, 1992, p. 39). Science can be differentiated to forma object science and non forma object science. The forma object science tries to intensively find the causes and it will not stop on the certain limitation (Poedjawijatna, 1991, p. 7).Philosophy and science meet on a certain point which is called as material object yet they are still different.

Sauri (2018, p. 17) inPendidikan Karakter dalam Perspektif Islam, states that religion plays a role as a value system that contains a certain norms as the reference of behaving and having attitude in order to be in accordance with the religion and belief. Allah SWT mentions in His holy book that human is created as khalifatullah fil $\operatorname{ardh}(\mathrm{QS}$. Al Baqarah [002]: 30). Human is created as the creature of truth seeker as Allah blesses with the intelligence which needs to be guided by religious values to prevent the bad contamination.

From the statements above, it could be concluded that science, philosophy, and religion have the same goal to find the truth, yet the three of those have different source of truth. The truth of science is not absolute and pragmatic, yet philosophy has the truth from radical, speculative, and universal thinking. Moreover, the truth of philosophy is based on the ratio thus it produces subjective and solipsistic truth (a perception of straightening self-opinion and accusing other's opinion). Religion is the entire belief, religious service, and duty that correlate to the belief. The truth of religion is absolute based on the belief and contains credo system. Religion shows the guidance of various scientific aspect including philosophy and life's aspects.

\section{B. The Correlation between Philosophy and Education}

Philosophy is a field of human's comprehensive thinking and investigation. It tries to critically, rationally, and comprehensively understand, analyze, assess, and conclude all problems relating to human's ratio (Syam 1986, p. 16). In education, philosophy educator has a role as a media to examine the theory of education and to find solution of a problem. Here philosophy and education realize goodness and happiness to the community. Education is a practical form of philosophy and an effective way to strengthen the educational principles and to achieve its 
goals. Therefore, the theories and objectives of education would be different in line with heterogeneity of philosophical values in a community.

The educational problems are the problems that connect to human's life thus education sometimes faces the problems that are disable to answer by comprehensive thinking and analysis (philosophy) (Syam,1986, p. 28). Therefore philosophy and education have a tight correlation. These then produce the philosophy of education; a philosophy that examines education and studies the process of life and the alternative process of nurturing character.

\section{The Correlation between Philosophy and Language}

One of the philosophy studies is language; language education has correlation to philosophy in deciding its educational process such as course, goals, and practice. Suriasumantri (1995, p. 175) describes the definition of language as a set of sound or symbol that forms a certain meaning. The sound represents an object. The comprehensive theory of philosophy is in the highest position of human's life, even as the ideology of a nation or country. Hence the theory of philosophy is as a source of social, political, economic, cultural, and education lives (Syam 1986, p. 28).

Relating to language education, philosophy has an important role and a tight correlation as the principles of deciding the goals and process of language teaching. As it is stated by Lubis (1994,p. 16-17), a science has three components as the pillar of science's body those are ontology (object of science), epistemology (process), and axiology (goals).

Discussing about language, we need to know about its definition, function, and advantage in human's life. Human is able to think well because of language. Without language, human is not able to think complicatedly and abstractly as these are done in scientific acts. Moreover, human cannot communicate the knowledge to others. Language forms human's ability to regularly and systematically think.
Suriasumantri (1995, p. 300-301) explains that language as a mean of communication to transfer a message covers three elements:(1)emotive (feeling) connotation; (2)affective connotation;and (3) reasoning connotation. The development of language is basically derived from those three aspects and it relates to the development of science and art. This condition can emerge language problems. The problems become matters of comprehensive thinking from modern philosophers. Abraham Kaplan inSuriasumantri (1995, p. 187) mentions that the assessment of philosophy including science, is logic-linguistic analysis. In a certain philosophy group such as analytical philosophy, language is not only a mean of philosophize and think, but also the basic material and final result of philosophy.

From the statements above, it can be concluded that language plays an important role in humans' interaction. Therefore, many philosophers provide theories of learning process and language acquisition on kids, teens, and even adults. Those theories are aimed to make the educators easier in analyzing, practicing, and comparing the appropriate theory to be applied in language teaching. Those theories are started from comprehensive and universal thinking in order to find the essential truth and it results a conclusion called as theory. Thus language teaching is dependent on philosophy as the consideration in theoretical arrangement and practical application.

Therefore in solving the language problems, the practitioners of language education must be able to implement philosophical thinking in order to find the roots of problems and to decide the suitable solution to solve the problems. To maximize the role of language as a mean of communication and integrative function, language education and development must be well systematized by philosophy application. Therefore learning philosophy is very important to educators especially language educators. 


\section{The Correlation of Philosophy, Geography, and Religion}

In scientific perspective, all of sciences have similar philosophy which is called as scientific method. Each science has same way to find knowledge such as rationalism and empirics thinking. John Dewey (1859-1952) arranges the marriage formulation of rationalism and empirics thinking applied by Galileo, Newton and Charles Darwin in previous era (Suriasumantri, 1995, p. 28). Rationalism is briefly explained as logical and coherent thinking design, whereas empiric is assessment design in ensuring the truth of science.

Socrates (470-399 SM) in Suriasumantri (1995, p. 4) "philosophy can be defined as a way of radical and comprehensive thinking that appeals something deeply". Radical, comprehensive, and deeply mean requiring long time to get a comprehensive and deep science. Furthermore, science is stated as a group of knowledge that has a certain characteristic. The field of a science is different from other ones based on the three main questions as the characteristics of a science: (1) ontology of science, (2) epistemology of science, and (3) axiologi of science. The answer how geography as a field of science can be treated as other fields is described as follow.

1. Ontology Aspects of Geography,including :

a) The concept of geography in etimology means earth science, in terminology it means a science that studies causal correlation between symptoms and phenomenon on Earth both its physical and the living creations as well as the problems through space, ecology, and regional approaches.

b) The scopes of geography are nature and humanity aspects.

c) The study objects of Geography are material object of geosphere such as atmosphere, lithosphere, hydrosphere, biosphere, and antropo-sphere; and formal objects such as space analysis, ecology, and region.

d) The concepts of geography cover: location, distance, extension, system, geomorphology, agglomeration, region diversification, purpose values, interaction, and space connection.

\section{EpistemologyAspect of Geography:}

The aim of epistemology is to find out the answers of questions.

3. Axiology Aspect of Geography:

a. Subjectivism (its use to human).

b. Logical Objectivism(results of examination, assessment, empiric).

c. Ethic and Aesthetic values QS. Ar Rum (30): 41.

Philosophy is derived from Greek "philosophia". "philein" (love), and "sophia" (wisdom). Thus someone who learns philosophy means someone who loves wisdom. Philosophy of geography means studying about the truth of geographical facts both Physical Geography and Social Geography or Human Geography. In a broad sense, after studying philosophy of Geography human will be the person who loves and cares environment.

The phenomenon of environmental damage occurs due to human's denying on universal lessons stated in Holy Qur'an and Sunnah Rasul. Thus, a comprehensive learning of environmental lessons and morals is absolutely needed to be taught and practiced as universal values. As it is stated by Sauri (2018, p. 165), human is a part of nature and environment, moreover human plays a role as khalifatullah fil ardh. Therefore human is demanded to care and protect the nature. Religious problems cannot be separated from human's life, as it is needed to regulate human's life (Sauri, 2018, p. 17). Islam teaches human to do shaleh to nature,shaleh here means appreciating nature and understanding the connection between natural components and life's aspects.

\section{CONCLUSIONS}

The conclusions of this study are mentioned below.

1. Philosophy, science, and religion are complementary each other in solving problems proposed by human. In addition 
three of them are the unity of pyramid in searching and finding the truth.

2. Interactive correlation between philosophy and education occurs in cultural circle and finally result philosophy of education.

3. Language cannot be separated from philosophy which provides the principles of

\section{REFERENCES}

Al-Qur'an dan Terjemahannya. 2008. Departemen Agama RI. Bandung: Diponegoro.

Bakar, Osman. 1997. Hirarki Ilmu. Bandung: Mizan.

Gazalba, Sidi . 1992. Sistematika Filsafat. Jakarta: Bulan Bintang.

Lubis, M. Solly. 1994. Filsafat Ilmu dan Penelitian. Bandung: Mandar Maju.

Mulkan, Abdul Munir. 1993. Paradigma Intelektual Muslim. Yogyakarta:Sipress.

Pidarta, Made. 1997. Landasan Kependidikan. Jakarta: Rineka Cipta.

Prasetya. 1997. Filsafat Pendidikan Islam. Bandung: Pustaka Setia.

Poedjawijatna. 1980. Pembimbing ke Arah Alam Filsafat. Jakarta:Pembangunan.

Poedjawijatna. 1991. Tahu dan Pengetahuan

Pengantar ke Ilmu danFilsafat. Jakarta:

Rineka Cipta.

Prasetya. 1997. Filsafat Pendidikan Islam. Bandung: Pustaka Setia.

Sadulloh, Uyoh. 2007. Pengantar Filsafat Pendidikan. Bandung: CV. Alfabeta.

Sauri, Sofyan. 2018. Pendidikan Karakter dalam Perspektif Islam. Bandung: Rizqi Press.

Suriasumantri, Jujun 1995. Filsafat Ilmu Sebuah Pngantar Populer. Jakarta: Pustaka Sinar Harapan.

Suseno, Franz Magnis.1995. Etika Dasar Masalah-masalah Pokok Filsafat Moral. Yogyakarta: Kanisius.

Syam, Muhammad Noor. 1986. Filsafat Kependidikan dan Dasar Filsafat Kependidikan Pancasila. Surabaya: Usaha Nasional.

Sumantri, Arif, 2010. Kesehatan Lingkungan dan Perspektif Islam. Jakarta: Kencana. educational process such as course, goals, and practice.

4. The correlation of philosophy, geography, and religion contextually emerges the character of environmental care that is relevant to the condition of Indonesia. Thus human can do the duty as khalifatullah fil ardh. 